\title{
Thomas B. Ferguson, MD
}

\section{Recipient, 2009 Lifetime Achievement Award American Association for Thoracic Surgery}

James L. Cox, MD

On May 11, 2009, the American Association for Thoracic Surgery presented its Lifetime Achievement Award to Thomas B. Ferguson, MD. Few surgeons of any generation have been so universally revered by their contemporaries as Tom Ferguson, the only living surgeon to have served as President of both the Society of Thoracic Surgeons (19761977) and the American Association for Thoracic Surgery (1981-1982).

Tom was born in Oklahoma, where his grandfather Ferguson was the first Territorial Governor of Oklahoma, his father was a successful newspaper publisher, and his mother, Lucia Loomis Ferguson, was quite famous as a nationally syndicated columnist fervently devoted to women's rights. Tom attributes his early interest in medicine to his grandfather Loomis, who upon graduating from the Cincinnati Medical School in the 1880s spent his life as a frontier doctor among the Choctaw Indians of the Oklahoma territory. After attending public schools in Oklahoma, Tom graduated from Duke University and then from its medical school and thereafter trained in surgery at both Duke and Barnes Hospital/ Washington University in St Louis with a year out to complete a Public Health Service fellowship in physiology at Harvard. With the exception of 4 years in private practice in Florida in the early 1960s, Tom's entire professional career has been spent in St Louis.

A simple litany of the awards that Tom Ferguson has received and the important positions that he has held during his career would exceed my allotted word count for this article. Tom has been honored with awards and appointments repeatedly by his friends and surgical colleagues in St Louis, by his alma mater, by his national and international surgical colleagues, and by virtually every organized body in his specialty. He has been the Chairman of the American Board of Thoracic Surgery (1974-1977), and he received the Distinguished Alumnus Award from Duke University in 1979. There is a Ferguson Lecture at Washington University in St Louis and another at the annual meeting of the Society of Thoracic Surgeons. Tom served 16 years as the Editor of the Annals of Thoracic Surgery (1984-2000) and 10 years as the Editor of CTSNet (2000-2009). During his tenure as

From the Division of Cardiothoracic Surgery, Washington University School of Medicine, St. Louis, Mo.

Address for reprints: James L. Cox, MD, 13523 Rosewood Lane, Naples, FL34119 (E-mail: jamescoxmd@aol.com).

J Thorac Cardiovasc Surg 2009;138:1051-2

$0022-5223 / \$ 36.00$

Copyright $₫ 2009$ by The American Association for Thoracic Surgery

doi:10.1016/j.jtcvs.2009.08.017
Editor of the Annals of Thoracic Surgery, the circulation of the journal, as well as its scientific credibility, increased dramatically as it expanded from 100 pages in Tom's first issue to 300 pages in his last issue. Tom is always the first to recognize the contribution of his long-time assistant and Managing Editor, Carol Blasberg, to the success of his tenure at the Annals. The subsequent decision to entice Tom to assume the editorial responsibilities of CTSNet not only ensured its success but also quite likely its very survival, and it is now perhaps the single most important organizational and educational tool in our specialty.

Despite the magnitude of his professional accomplishments, which have only been skimmed here, the thing that people closest to Tom most appreciate is Tom himself. It is obvious that he genuinely likes other people, and that feeling is reciprocated by everyone who meets him. It is not uncommon for men of small accomplishment to be liked by everyone, but few men of major accomplishment are so universally beloved as Tom Ferguson. Of course, he has not achieved his station in life through his efforts alone. Like most successful men, Tom's success is entwined with that of his wife of many years, Libby. They met as undergraduate students at Duke and have subsequently lived the American Dream, he as an accomplished surgeon, she as an accomplished magazine publisher. The story goes that when the St Louis Magazine failed in the late 1970s, Tom bought it for one dollar and gave it to Libby. Rather than treat it as a sentimental joke, Libby turned it into the most popular and essential magazine in the city, one that businessmen, politicians, civic leaders, sports figures, doctors, and lawyers all considered a must read. A favorable word on a restaurant in the St Louis Magazine during the Libby Ferguson Era ensured instant success for that restaurant, and of course, the opposite was true as well.

While pursuing separate careers that too often demand levels of narcissism most conducive to a dysfunctional family, Tom and Libby raised 3 wonderful children who all became quite successful in their personal and professional lives, living testaments to the quality of their parents as parents. One of them, T. Bruce Ferguson, Jr, MD, has become a leader in American thoracic surgery and an indispensable watchdog over the quality of clinical practice in cardiothoracic surgery both here and abroad. Though immensely successful in all areas of life, nevertheless, Libby and Tom do share one weakness that is sometimes painful to witness... their love for the St Louis Cardinals. In 1982, 1985, 1987, 2004, and 2006 the Cardinals were in the World Series, but neither Tom nor Libby could attend the games or even 
watch them on television...it was simply too nerve-wracking for them. One would think that such an accomplished pair would not be squeamish about anything, but not so when it involves the Fergusons and the Cardinals!

Tom's easy-going demeanor masks an underlying steeliness of resolve that even those who have worked closely with him often miss, but they do so at the risk of underestimating this man's remarkable ability to effect positive change in his every endeavor. A testament to the level of that resolve was on display one rainy day in October 1982 in a parking lot on the campus of Duke University. I was a young assistant professor contemplating a potential move from the comfortable cocoon of cardiac surgery at Duke to the wild west shootout that was brewing in St Louis. Indeed, within 2 years of that October day in Durham, the number of hospitals performing cardiac surgery in St Louis was destined to increase from 3 hospitals to over a dozen hospitals! At that time, successful large city clinical practices in cardiothoracic surgery were very lucrative, and Tom and his incomparable surgical partner of more than one-half century, Charlie Roper, had already been in practice together there for nearly a quarter century. Nevertheless, they both volunteered to enter full-time university status on fixed incomes that were less than $50 \%$ of their usual income. When I asked rather incredulously why 2 successful private surgeons would even contemplate such a move, Tom's answer was "Because you will never talk to anyone ever again who wants to see the Division of Cardiothoracic Surgery at Washington University become the best in the country as much as Charlie and I do." Fortunately for me, I did join them, and shortly thereafter, they both joined the
Division as full-time employees at a huge personal sacrifice of a magnitude that until this article has always been known only to me. No young division chief could possibly have had a better pair of men "watching his back" during those difficult first few years. Needless to say, the subsequent ability to attract internationally renowned surgeons to our division in St Louis, many of whom are still there, was greatly enhanced by having Tom Ferguson as a faculty member. Even my future father-in-law, also a Duke-trained and renowned physician at Barnes Hospital and Washington University for more than 30 years at the time, personally vetted me through Tom Ferguson and Charlie Roper before deciding whether or not to bless the budding courtship between his beautiful daughter and this new guy from Duke with all the rough edges! Now that is what I call support!

Tom Ferguson's immensely successful, yet seemingly effortless, navigation through the corridors of academia has forever dispelled the notion that greatness demands abusive power, harshness, or control. Rather, Tom's greatness has been built on genuine substance, uncommon grace, singular generosity, and an infectious laugh. Young surgeons of today need only look at Tom Ferguson to see the model to which they should all aspire, both as surgeons and as human beings.

Some of you know that one of my favorite quotes is from G. K. Chesterson, and I have often thought that it must have been written specifically with Tom Ferguson in mind. "There are great men who make every other man feel small. But the truly great man is the man who makes every other man feel great."

Like virtually every other man who has been privileged to know him well, Tom Ferguson always makes me feel great. 